\title{
Engagement of Children with Special Educational Needs in Accordance with the Routines-Based Model
}

\author{
Sylwia Wrona ${ }^{1}$ and Kamila Wrona ${ }^{1}$ \\ ${ }^{1}$ University of Silesia in Katowice, Poland
}

HOW TO CITE:

Wrona, S., Wrona, K. (2021).

Engagement of Children with Special Educational Needs

in Accordance

with the Routines-Based Model.

International Journal of Special

Education, 36(1), 27-34

CORRESPONDING AUTHOR:

Sylwia Wrona;

sylwia.wrona@us.edu.pl

DOI:

https://doi.org/10.52291/

ijse.2021.36.3

COPYRIGHT STATEMENT:

Copyright: (C) 2021 Authors.

Open access publication under the terms and conditions of the Creative Commons

Attribution (CC BY)

license (http://creativecommons.

org/licenses/by/4.0/).

\begin{abstract}
Engagement of a child with SEN during therapeutical and educational activities is important in terms of their development. This construct can be understood as the time the child spends interacting with adults, peers and materials, in a manner appropriate for their developmental age. Routines-Based Model is one of the methods which particularly promotes engagement. This study aims at measuring the level of engagement in certain preschool routines and its changes during the school year. The article consists of two parts; the first one presents issues connected with defining and identifying the levels of engagement, the second one discusses the studies connected with determining the level of engagement of children with special educational needs in the process of education.

The analysis of study results indicates that children in the tested group achieve the highest scores in overall engagement and engagement with materials. The highest level of engagement throughout the year has also been observed in those categories.
\end{abstract}

Keywords: engagement; Routines-Based Model; education of children with special educational needs 


\section{ENGAGEMENT}

In inclusive, integrated and even special education, we can observe different levels of engagement of a child with a disability into the proposed educational, therapeutical and care activities. We can very often observe a situation where children without dysfunctions follow the proposed activities while those with greater developmental problems usually watch them, wander without a purpose around the classroom or activate well known stereotypic behaviour.

Therefore, when we observe different types of behaviour in response to the proposed activities, a question arises - what is engagement and how can we determine whether the child fully uses the educational, therapeuti$\mathrm{cal}$ and care provision in the facility and most importantly, whether we can examine that activity and determine its changes.

Child's engagement is defined as the amount of time children spend interacting in a manner appropriate for their age, abilities, and surroundings (McWilliam, Bailey 1992).

\section{The construct of "child's engagement" in opposition to "taking part in a certain activity" applies to all types of behaviour. It is classified according to:}

- type: interaction with adults, peers and materials;

- levels - from sophisticated to nonengagement (see Table 1);

- amount - per cent of time in which we observe a certain type and level of engagement.

Such detailed description of engagement enables teachers to describe and measure children's behaviour accurately (McWilliam, de Kruif, 1998). During the assessment we should take into consideration the developmental and contextual adequacy in order to recognize the child as engaged. The child must behave in a way that can be expected of them as appropriate for their level of development and not biological age. The contextual perspective is connected with the duration of a behaviour in a certain situation (context) and not with performing individual tasks e.g. in a test situation (McWilliam, Casey, 2008). It is considered that the child's engagement plays a vital role in their education and development (McWilliam et al. 1985). It is seen as a variable between the environment and achievements (Greenwood, Carta, Dowson, 2000). Measurement of the level of children's engagement is a key factor in identifying the areas that require changes in educational, therapeutical and care activities in order to suit them to children's abilities and to support them (Downer, Booren, Lima, Luckner \& Pianta, 2010) as well as to improve the quality of early education (Murillo, Garcia Grau, Dolores Grau, 2020; Casey, McWilliam, 2015; Ridley et al 2000, McBride \& Schwatz, 2003; Duda, Dunlap, Fox, Lentini, \& Clarke, 2004). The traditional scales and tests e.g. general intelligence tests examine different skills. The results are used to diagnose a certain function without direct recommendation to introduce educational and therapeutical changes in the typical environment of a toddler. Measurement of engagement allows for a direct focus on the functional routines. Such approach is useful while measuring the engagement as a result of checking the effectiveness of using educational interventions. (Kishida, Kemp, 2006). It is very important in case of education of children with disabilities, as the seriousness of the disability may influence their ability to do a certain task. In order to provide the children with conditions that foster their engagement, we have to take into account the possibility of giving them physical prompts that are necessary to ensure active or passive engagement. Additionally, the type of disability determines the character of support provided (Kishida, Kemp, 2006). Children with autism spectrum need more attention to build engagement in relations with another person while a child with a physical disability needs more attention to adjust e.g. the toys and access to them. Until now, the level of engagement of children with disabilities has not been tested in Poland.

It is in the children's nature to be curious of the world. They are interested in everything that surrounds them. The preschool period is frequently defined as an age of questions and preschool children are compared to little experimenters or researchers (Brzezińska, 2014; Szuman, 1985). They examine, observe, draw conclusions - the learning process takes place throughout a child's activity. Consequently, the environment the child functions in must be friendly and encourage them to explore the world freely, irrespectively of their skill and capabilities (Hornowska, Brzezińska, Appelt, and Kaliszewska-Czeremska, 2014; Weisberg, Hirsh-Pasek,Golinkoff, Kittredge, and Klahr, 2016).

The classes run according to Routines-Based Model (RBM) are aimed at all children, regardless of their level of functioning. The adaptation of main rules favors inclusive education of children with special educational needs, but may also be used in special education. This model has been in use in Poland since September 2018 in Stoneczna Kraina (Sunny Land) Therapeutical Preschool in Cieszyn. It is the first facility which introduced the model into the Polish education market. 
Table 1.

\begin{tabular}{|c|c|c|}
\hline Level & DESCRIPTION & Category \\
\hline Persistence & $\begin{array}{l}\text { The most sophisticated level of engagement. It involves problem solving and overcoming cer- } \\
\text { tain challenges. It also involves changing strategies or using the same strategy again to solve } \\
\text { the problem or reach a goal. Example: a child attempts to do a jigsaw puzzle but struggles } \\
\text { with matching the pieces so they try to match two pieces in several ways }\end{array}$ & \multirow{4}{*}{ SOPHISTICATED } \\
\hline $\begin{array}{l}\text { Symbolic } \\
\text { behaviour }\end{array}$ & $\begin{array}{l}\text { It includes the use of conventional forms of behaviour (e.g. language, pretend play) to talk } \\
\text { about the past and future and to construct new forms of expression through combinations of } \\
\text { different symbols and signs. The major characteristic of symbolic behaviour is decontextu- } \\
\text { alization or the capability to communicate about someone not physically present. Examples: } \\
\text { pretend play, the child pretends to cook in the playground, talks about a trip that was taken } \\
\text { last week or uses a block to "brush" a doll's hair }\end{array}$ & \\
\hline $\begin{array}{l}\text { Encoded } \\
\text { behaviour }\end{array}$ & $\begin{array}{l}\text { It includes the use of understandable language to communicate. An important aspect of en- } \\
\text { coded behaviour is that it must be context bound. Example: the child communicates about } \\
\text { objects or events in the immediate environment, e.g. about a game they are playing or about } \\
\text { what a peer is doing at the table }\end{array}$ & \\
\hline $\begin{array}{l}\text { Constructive } \\
\text { behavior }\end{array}$ & $\begin{array}{l}\text { It applies only to play with materials. In includes manipulating objects to create, or build } \\
\text { something. There is some indication of intentionality. Examples: drawing a picture, building } \\
\text { a tower with blocks }\end{array}$ & \\
\hline $\begin{array}{l}\text { Differentiated } \\
\text { behaviour }\end{array}$ & $\begin{array}{l}\text { It involves coordination and regulation of behaviors, reflecting the preparation and progress to } \\
\text { conventionalization; it involves active interaction with the environment. In some studies, this } \\
\text { level of engagement has been called "participation", because it entails behaviour appropriate } \\
\text { for the context. Example: the child uses a spoon to eat during the meal }\end{array}$ & \multirow{2}{*}{$\begin{array}{l}\text { DIFFERENTIATED } \\
\text { PARTICIPATION/ } \\
\text { FOCUSED } \\
\text { ATTENTION }\end{array}$} \\
\hline $\begin{array}{l}\text { Focused } \\
\text { attention }\end{array}$ & $\begin{array}{l}\text { Focused attention includes watching or listening to features in the environment and must } \\
\text { involve directly looking at a feature. Attention must be sustained for at least } 3 \text { seconds. Focu- } \\
\text { sed attention is characterized by a serious facial expression and a quieting of motor activity } \\
\text { extraneous to the task at hand. The child responds to a narrow range of stimuli. Example: } \\
\text { listening to a story or reading a book }\end{array}$ & \\
\hline $\begin{array}{l}\text { Undifferentiated } \\
\text { behavior }\end{array}$ & $\begin{array}{l}\text { The child interacts with the environment without changing the characteristics of his or her be- } \\
\text { haviour (i.e., performs a behaviour in a repetitive manner), using simple, low-level behaviour } \\
\text { patterns. Undifferentiated behaviour is not necessarily negative; it might be connected with } \\
\text { the level of development the child is currently at. Example: the child keeps hitting two blocks } \\
\text { or rolls a car back and forth }\end{array}$ & \multirow[t]{2}{*}{ UNSOPHISTICATED } \\
\hline Casual attention & $\begin{array}{l}\text { It includes relaxed and wide-ranging attention. The child must be looking at something for a } \\
\text { total of at least } 3 \text { seconds. However, the child is attending to a sequence or a range of things } \\
\text { in a sequence within } 3 \text { seconds as opposed to attending to one object or person. Example: } \\
\text { the child looks around the room to see what activity centres are open, looks at the people, } \\
\text { objects, activities. }\end{array}$ & \\
\hline Nonengagement & $\begin{array}{l}\text { The child is unoccupied (not engaged in any activity), e.g.: } \\
\text { - waiting needlessly (i.e. not in a turn-taking situation) } \\
\text { - waiting even though it knows what is coming next and is anticipating the activity } \\
\text { (e.g., sitting at the table waiting for food) } \\
\text { - staring blankly } \\
\text { - wandering without a purpose } \\
\text { - crying, whining } \\
\text { - displaying aggressive or destructive acts } \\
\text { - breaking sensible rules (throwing or kicking toys). }\end{array}$ & NONENGAGEMENT \\
\hline
\end{tabular}

\section{The following statements, directly connected with engagement, underpin the introduction of RBM:}

- Basic assumption of the method stems from the theory of learning, according to which the more a person is interested in something, the faster they acquire the knowledge of a certain issue (Dunst, Raab, Trivette, and Swanson, 2010; Dunst, Herter, and Shields, 2000; Widerstrom, 2005). Studies prove that children with special educational needs spend less time interacting with adults, peers, and materials and most of the time they are not engaged in any activity or they are engaged at a very low level, i.e. wandering without purpose, clapping their hands or displaying stereotypic movement disorders (Weisberg, Hirsh-Pasek, Golinkoff, Kittredge, and Klahr, 2016);

- Child's engagement might be increased by arranging the child's environment - a special arrangement of space in the classroom which "invites" the child to engaged participation in various activities (McWilliam, Casey, 2008; Weisberg, Hirsh-Pasek, Golinkoff, Kittredge, Klahr, 2016); 
- Incidental teaching allows for following an individual need of the child, at the same time strengthening their interests and introducing and consolidating the core curriculum. (Casey, McWilliam, Sims, 2012; McGee, Morrier, Daly, 1999).

\section{MATERIALS AND METHODS}

The purpose of this study was to check how, during the school year, the engagement of children who learn according to the guidelines of Routines-Based Model, changes, and to compare the categories of the engagement. The engagement was measured with STARE (The Scale for Teacher's Assessment of Routines Engagement). It is a teacher's scale to measure the engagement of a child into routines. The elements being measured are the level of engagement and the amount of time a child is engaged with adults, peers and materials. Those elements form the assessment of overall engagement. A child is observed every day and filling in the form takes only a few minutes. The scale can be used for:

- examining child's engagement during a certain unit of time (month, year, etc.) and comparing the results in all observed aspects which allows for determining the level of child's engagement and its changes;

- determining the effectiveness of the educational/care and therapeutical activities by analyzing the results of the child's engagement after the teacher's "intervention" which aims at, e.g. increasing the engagement with a peer instead of an adult;

- analyzing the engagement trend, e.g. by determining which routines create bigger or smaller engagement in a child, which may result in changes in the organization of the daily schedule;

- communicating with the family or other specialists about how the child participates in the activities organized in an institution.

In this study the teachers filled in STARE in a form of a questionnaire after observing children's behaviour in a group. First of all, in every preschool routine (i.e. in arrival, music, small group, story) the teachers assessed the length of time of a child's overall engagement and then specified it in the following categories: with adults, peers and materials on a 5-level scale (where 1 means almost none of the time and 5 means almost all of the time) as well as the level of engagement (from nonengagement to sophisticated engagement) (McWilliam, 2000). The results are calculated by taking the mean of 5 variables, i.e.: overall engagement, engagement with peers, adults, ma-
Table 2.

Types of disabilities of the study's subjects

\begin{tabular}{l|c|c}
\hline \multicolumn{3}{l}{ Types of disabilities among the subjects } \\
\hline Type of Disability & Frequency & Percent \\
\hline autism & 4 & 21.05 \\
\hline physical disability, including aphasia & 5 & 26.32 \\
\hline hearing impairment & 1 & 5.2 \\
\hline multiple disabilities & 9 & 47.37 \\
\hline missing & 0 & 0.00 \\
\hline total & 19 & 100.00 \\
\hline
\end{tabular}

terials and quality of engagement, from the results which include all examined routines. Before the statistical analyses were carried out, an analysis of the tools reliability had been carried out with the following result: alpha $=.86$

\section{PARTICIPANTS}

Nineteen children took part in the study, including 13 boys $(68.42 \%)$ and 6 girls (31.58\%) who attended Słoneczna Kraina (Sunny Land, Poland) Therapeutical Preschool. The mean age was $M=5.26$. During the first study, the youngest child was 3 years old, and the oldest was 7 years old. All children attending the facility had a special educational needs statement. Table 2 presents types of disabilities among the children according to the diagnoses provided in each statement. All children who took part in the study attended preschool from the beginning of the school year in the groups working in line with the Routines-Based Model method.

The studies were carried out by the teachers of target preschool's groups from the beginning of the school year, i.e. from September 2019 until August 2020, at least once a month. All statistical analyses were conducted with the use of JASP 0.11.1.

\section{RESULTS}

\section{Engagement}

Table 3 presents the descriptive statistics and the statistics concerning the distribution of examined variables. All results were divided into three periods according to the school year. The first period is the mean of study results from September 2019 to December 2019 (I), the second period from January 2020 to March 2020 (II) and the third period from May 2020 to August 2020 (III). No studies were carried out in April due to the lockdown of 
Table 3.

Descriptive statistics

Descriptive statistics

\begin{tabular}{|c|c|c|c|c|c|c|c|c|c|c|c|c|c|c|c|}
\hline & $\underset{I}{O E}$ & $\begin{array}{l}\text { A } \\
\text { I }\end{array}$ & $\begin{array}{l}P \\
\text { I }\end{array}$ & $\begin{array}{c}M \\
I\end{array}$ & $\begin{array}{l}\text { C } \\
\text { I }\end{array}$ & $\begin{array}{c}\text { OE } \\
\text { II }\end{array}$ & $\begin{array}{l}\text { A } \\
\text { II }\end{array}$ & $\begin{array}{l}\text { P } \\
\text { II }\end{array}$ & $\begin{array}{l}\text { M } \\
\text { II }\end{array}$ & $\begin{array}{l}\text { C } \\
\text { II }\end{array}$ & $\begin{array}{l}\text { OE } \\
\text { III }\end{array}$ & $\begin{array}{c}\text { A } \\
\text { III }\end{array}$ & $\begin{array}{l}\text { P } \\
\text { III }\end{array}$ & $\begin{array}{l}\text { M } \\
\text { III }\end{array}$ & $\begin{array}{c}\text { C } \\
\text { III }\end{array}$ \\
\hline Valid & 19 & 19 & 19 & 19 & 19 & 19 & 19 & 19 & 19 & 19 & 12 & 12 & 12 & 12 & 12 \\
\hline Missing & 0 & 0 & 0 & 0 & 0 & 0 & 0 & 0 & 0 & 0 & 7 & 7 & 7 & 7 & 7 \\
\hline Mean & 4.36 & 3.19 & 3.02 & 4.15 & 3.23 & 4.40 & 2.94 & 3.08 & 4.02 & 3.32 & 4.72 & 2.94 & 3.25 & 4.43 & 3.33 \\
\hline Std. Deviation & 0.34 & 0.45 & 0.72 & 0.33 & 0.24 & 0.32 & 0.31 & 0.82 & 0.40 & 0.34 & 0.19 & 0.51 & 0.82 & 0.38 & 0.34 \\
\hline Shapiro-Wilk & 0.96 & 0.97 & 0.92 & 0.95 & 0.96 & 0.93 & 0.97 & 0.94 & 0.96 & 0.90 & 0.91 & 0.96 & 0.85 & 0.82 & 0.95 \\
\hline P-value of Shapiro-Wilk & 0.63 & 0.72 & 0.12 & 0.39 & 0.55 & 0.19 & 0.81 & 0.27 & 0.55 & 0.06 & 0.20 & 0.83 & 0.04 & 0.02 & 0.69 \\
\hline Minimum & 3.83 & 2.04 & 2.01 & 3.57 & 2.74 & 3.78 & 2.31 & 1.20 & 3.28 & 2.86 & 4.27 & 2.21 & 1.64 & 3.40 & 2.80 \\
\hline Maximum & 5.00 & 3.97 & 4.23 & 4.83 & 3.62 & 4.83 & 3.60 & 4.18 & 4.80 & 4.22 & 4.95 & 3.84 & 4.07 & 4.86 & 3.88 \\
\hline
\end{tabular}

*OE - Overall Engagment; A - With Adults; P - With Peers; $\mathbf{M}$ - With Materials; $\mathbf{C}$ - Complexity

** I - first period from September to December 2019; II - second period from January to March 2020; III - third period from May to August 2020

all educational facilities caused by the sanitary restrictions connected with SARS-CoV-2 pandemic. The data below show that children had the best results in Overall Engagement and with Peers categories. In all three periods the mean Overall Engagement reached the value of over 4 $(\operatorname{Min}=4.36 ; \operatorname{Max}=4.72)$. Similar results were reported in the category Engagement with Materials (Min = 4.02; Max $=4.43$ ). In order to do further statistical analyses, the normality distribution of the distribution of variables was checked. Shapiro-Wilk test results indicate that three variables - Overall Engagement III, with Peers III and with Materials III are statistically significant $(\mathrm{p}<.05)$.

\section{Comparison of engagement categories}

In the beginning, the differences between engagement categories among the subjects were checked. To this end, Friedman test was carried out and in the first $($ Chi2(2) =

Table 4.

Types of engagement comparison. Post hoc analysis

Conover's Post Hoc Comparisons - Types of engagment

\begin{tabular}{cc|c|c|c|c|c|c|c}
\hline & & T-Stat & $\mathbf{d f}$ & $\mathbf{W i}$ & $\mathbf{W i}$ & $\mathbf{p}$ & phonf & pholm \\
\hline A I & P I & 0.33 & 36 & 29.50 & 27.50 & 0.75 & 1.00 & 0.75 \\
\hline & M I & 4.49 & 36 & 29.50 & 57.00 & $v .001$ & v.001 & v.001 \\
\hline P I & M I & 4.82 & 36 & 27.50 & 57.00 & v.001 & v.001 & v.001 \\
\hline A II & P II & 0.81 & 36 & 27.00 & 32.00 & 0.42 & 1.00 & 0.42 \\
\hline & M II & 4.54 & 36 & 27.00 & 55.00 & $v .001$ & v.001 & v.001 \\
\hline P II & M II & 3.73 & 36 & 32.00 & 55.00 & $v .001$ & 0.00 & 0.00 \\
\hline A III & P III & 0.62 & 22 & 16.50 & 19.50 & 0.54 & 1.00 & 0.54 \\
\hline & M III & 4.03 & 22 & 16.50 & 36.00 & v.001 & 0.00 & 0.00 \\
\hline P III & M III & 3.41 & 22 & 19.50 & 36.00 & 0.00 & 0.01 & 0.01 \\
\hline
\end{tabular}

28.99; $\mathrm{p}=<.001 ;$ Kendall's $\mathrm{W}=.50)$, second $(\mathrm{Chi} 2(2)=$ 23.47; $\mathrm{p}=<.001 ;$ Kendall's $\mathrm{W}=.40)$ and third $(\mathrm{Chi} 2(2)=$ 18.77; $\mathrm{p}=<.001$; Kendall's $\mathrm{W}=.25)$ measurement it indicated statistically significant differences between the categories that children were engaged with. Table 4 presents the results of post-hoc analysis with Conover test.

In all three tested periods Engagement with Materials was significantly higher that Engagement with Adults ( $\mathrm{p}<$ $.001)$ and with Peers $(\mathrm{p}<.001)$.

\section{Change of engagement over the school year}

In order to check the change of engagement (Figure 1), in particular categories over the school year, Friedman Test was carried out (Table 5).

The test showed a statistically significant change in the Overall Engagement over the school year: Chi2 $(2)=8.67$; $\mathrm{p}=.01 ;$ Kendall's $\mathrm{W}=.37$.

Table 5. Change of engagement. Friedman test's results

\begin{tabular}{l|l|c|c|c|c}
\hline \multicolumn{6}{l}{ Friedman Test } \\
\hline Variable & Factor & Chi-Squared & $\mathbf{d f}$ & $\mathbf{p}$ & Kendall's W \\
\hline OE & Months & 8.67 & 2 & 0.01 & 0.37 \\
\hline WA & Months & 2.00 & 2 & 0.37 & 0.28 \\
\hline WP & Months & 0.17 & 2 & 0.92 & 0.86 \\
\hline WM & Months & 8.17 & 2 & 0.02 & 0 \\
\hline C & Months & 3.19 & 2 & 0.20 & 0.73 \\
\hline
\end{tabular}

OE - Overall Engagment; $\mathbf{A}$ - With Adults; $\mathbf{P}$ - With Peers;

M - With Materials; C - Complexity 


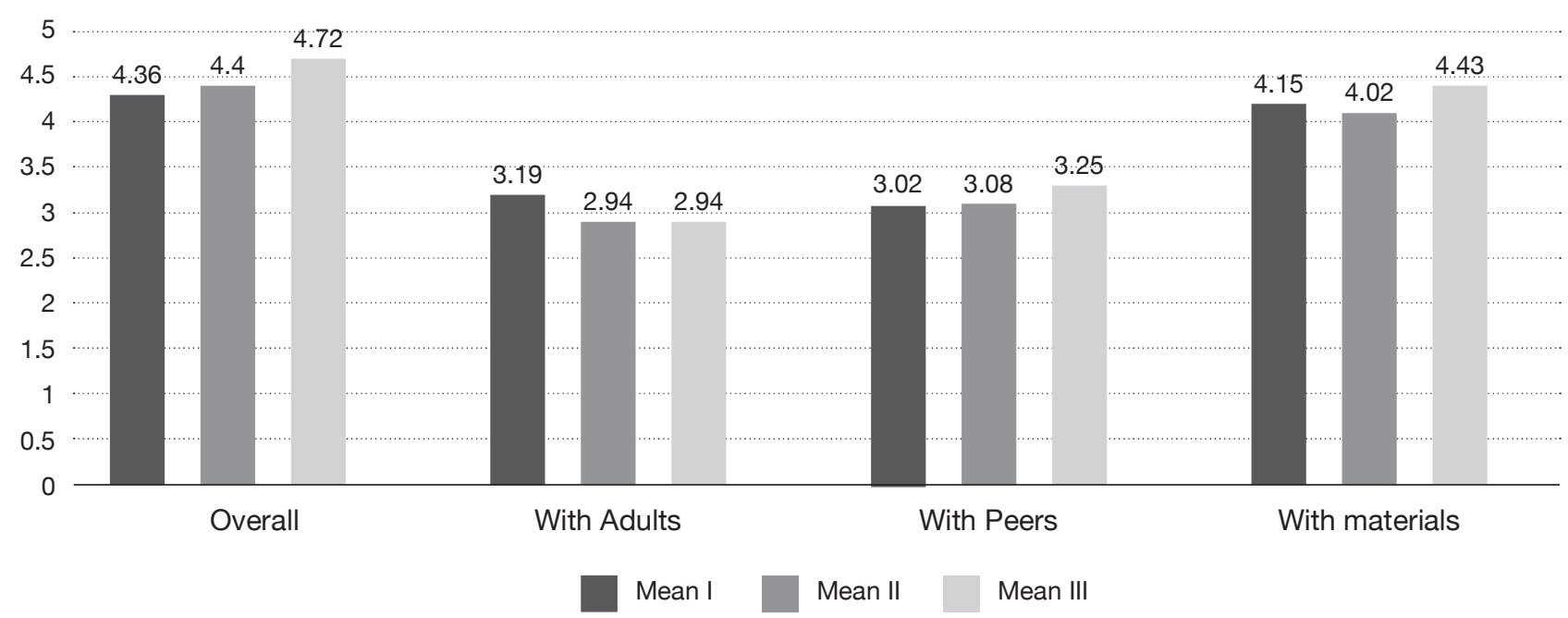

Figure 1.

Mean values in each type of engagement during the school year

Post hoc analysis with Conover test indicated that in the third measurement the subjects received statistically higher results than in the first measurement $(\mathrm{p}=.01)$ and in the second $(\mathrm{p}=.05)$, as shown in Figure 2.

Additionally, Friedman's test indicated differences in Engagement with Materials Chi2(2) = 8.17; $\mathrm{p}=.02$; Kendall's $\mathrm{W}=.52$, similarly to Overall Engagement. Post hoc test showed that the Engagement increased between the first and third measurement $(\mathrm{p}=.04)$, as well as between the second and the third $(\mathrm{p}=.01)$. The change can be observed on Figure 3 below.

In case of other variables, statistically significant differences have not been observed. However, it is worth paying attention to the effect size, which in case of Engagement with Peers was $\mathrm{W}=.86$. This indicates the strength of the effect and in the case of Quality it was W $=.73$ (average effect).

Taking into consideration the above results, Wilcoxon test was carried out and on its basis the information about the effect was gained (Field, 2018). In the beginning,

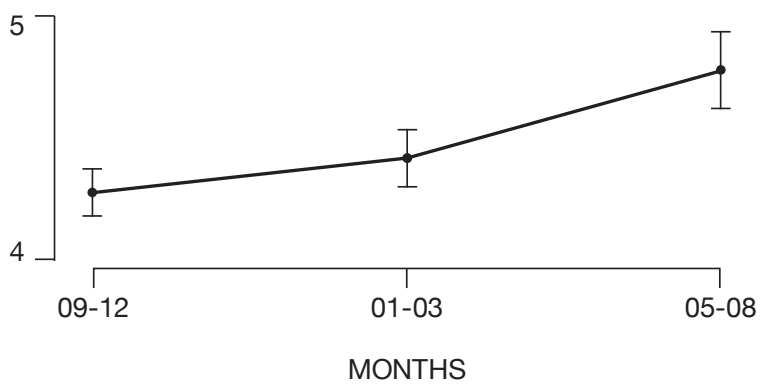

Figure 2.

Change of Overall Engagement in three measurements. the measurements of Engagement with Peers were compared. The strength of the effect for the comparison of the first and third measurement was $\mathrm{rc}=.52 ; 95 \% \mathrm{CI}$ $[-.70, .38]$ and for the second and third it was $\mathrm{rc}=-.42$; $95 \%$ CI $[-.80, .19]$, which suggests that work in the examined model matters to the change of Engagement with Peers. In case of engagement quality, the strength of the effect for the comparison of the first and third measurement was $\mathrm{rc}=-.49 ; 95 \% \mathrm{CI}[-.83, .11]$, which might be interpreted as average effect (King, Minium, 2020).

\section{DISCUSSION}

The quality of children's engagement ranged from focused attention to differentiated participation. The result obtained shows that the tested children are active in interactions with the environment and behave adequately to the educational situation they found themselves in, e.g. by being focused while listening to the teacher's story, be-

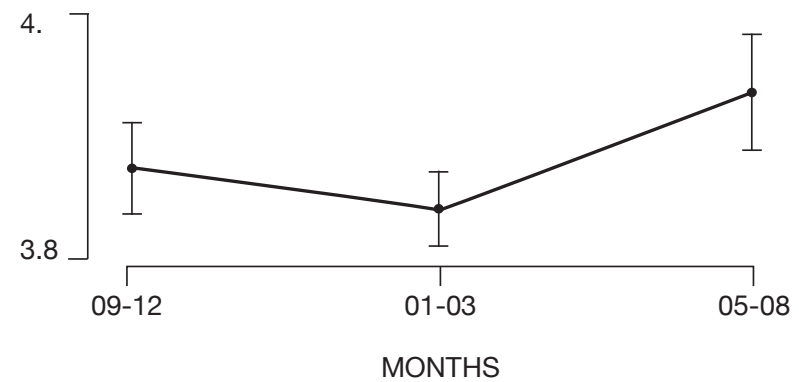

Figure 3.

Change of Engagement with Materials in three measurements. 
ing independent in the cloakroom and in the bathroom. Despite no statistically significant differences the effect size reached $\mathrm{W}=.73$. This result allows for an assumption that the quality of engagement in tested groups has an upward trend.

STARE results indicate that mean overall engagement is a little above 4 points $(\min =4.36 ; \max =4.72)$, and the quality (level) around 3 points $(\min =3.23$; $\max$ $=3.33$ ). It means that children remain in active interactions with the environment for most of the time. The obtained results show a statistically significant change between measurements I and III as well as between II and III. Mean level of overall engagement increased during the period of school year. In case of the tested group the lowest mean concerned Engagement with Adults $(\mathrm{min}=$ 2.94; $\max =3.19)$ and Peers $(\min =3.02 ; \max =3.25)$. Mean results concerning Engagement with Adults remain at a stable level and prove that children are well engaged in the proposed activities. At the beginning of early education the teacher plays a role of a person who guarantees security and determines the rhythm of activities. While running the educational classes with RBM method the engagement of the teacher changes too. They show, inspire, and use incidental teaching and then they withdraw from children's activities to play the role of an observer. Their main task is to inspire and make sure that children's engagement and well-being are maintained (Cadima et al., 2019). It is possible that the growth of children's competences results in them not seeking permanent contact with the teacher, and the teacher's role is limited to helping with solving conflicts or modelling the required behaviour. It should be noted that RBM does not promote permanent work of a child and a teacher. Its main task is to include the children in the activities which broaden and enrich the knowledge and competences of the children (Grisham-Brown et al., 2017), and the main purpose is to develop social relations with peers which require certain social competences from children. The result achieved in Engagement with Peers is satisfying, taking into account the fact that the group consists of children with autism spectrum and multiple disabilities, many of which are connected with impaired communication. It is satisfying that, despite the lack of statistical significance of the results, the strength of the obtained effect may suggest that the development trajectory of this kind of engagement has an upward trend. It means that the way of conducting the classes fosters establishing and maintaining social interactions with peers despite the difficulties that result from a disability (e.g. communicative, sensory). Nevertheless, it is a field that requires further support and promotion of the development of competences, which in turn foster developing relations with peers.

The obtained results indicate an increased Engagement with Materials rather than with Adults or Peers. Trajectory of Engagement with Materials has an upward trend. The basic task of a teacher in RBM is to engage a child into an activity of their choice. The teacher who wants to attract the child's attention arranges a situation in which the children can independently explore new materials. Such actions are also in line with the rule of multi-sensory cognition of reality. Another justification of the obtained results is an increased attention of the teachers connected with the development of children's competences in independent play. The interviews conducted with parents often show that the area of common purpose to work on (in preschool and at home) during a school year is connected with independent play. The parents' aims are important in planning the teacher's activities. Relating to the assumptions of RBM model, it can be stated that children's engagement has an upward trend and results from the implemented educational practices.

\section{Limitations and subjects for future studies}

The performed analysis of the types and levels of engagement in children with special educational needs is the first attempt of this kind of studies for Polish special education at the preschool level. The tool itself, to the best of authors' knowledge, is not used in domestic educational facilities. It is due to the fact that the studies were carried out in a preschool that is the first to implement RBM method in Poland. The study of engagement level and its types is one of the practices applied by the model.

The limitations of the study include the fact that the test sample was small. The sample size may condition the lack of statistical significance of some of the results in Friedman test (Ferguson, 2009). The changing number of subjects, caused by the COVID 19 pandemic situation in Poland (closed educational facilities, numerous quarantines, etc.), is also among the limitations that need to be taken into account while interpreting the studies' results.

Future studies may focus on testing the engagement in particular daily routines. It would allow for determining the areas that require reframing in terms of group functioning (e.g. routines' order). An interesting addition would also be to perform a comparison in terms of engagement of children in special groups run with RMB method with the groups run in a "traditional" method of work. 
Further studies concerning the levels, types and quality of engagement of children in preschool education during the routines may help in improving the quality of education and the activities integrating the children with special educational needs into inclusive and regular facilities.

\section{ACKNOWLEDGEMENT}

None.

\section{DISCLOSURE STATEMENT}

No potential conflict of interest was reported by the authors.

FUNDING: None.

\section{REFERENCES}

Brzezińska, A. (2014). Rozwój w okresie dzieciństwa i dorastania. in. Brzezińska, A. (Eds) Poradnik dla nauczycieli. Warszawa: Instytut Badań Edukacyjnych.

Casey, A. M., McWilliam, R. A., \& Sims, J. (2012). Contributions of incidental teaching, developmental quotient, and peer interactions to child engagement. Infants \& Young Children, 25, 122-135.

Casey, A.M., McWilliam, R.A., (2015). The STARE: the scale for teachers' assessment of routines engagement. Young Exceptional children, 11 (1), 1-15.

Cadima, J., Barros, S. Ferreira, T., Serra-Lemos, M., Leal, T. \& Verschuren K. (2019). Bidirectional associations between vocabulary and self-regulation in preschool and their interplay with teacher-child closeness and autonomy support. Early Childhood Research Quarterly, 46, 75-86.

Downer, J.D., Booren, L.M., Lima, O.K., Luckner, A.E. \& Pianta R.C., (2010). The Individualized Classroom Assessment Scoring System (inCLASS): Preliminary reliability and validity of a system for observing preschoolers' competence in classroom interactions. Early Childhood Research Quarterly, 25 (1), 1-16.

Duda, M. A., Dunlap, G., Fox, L., Lentini, R., \& Clarke, S. (2004). An experimental evaluation of positive behavior support in a community preschool program. Topics in Early Childhood Special Education, 24, 143-155.

Dunst, C. J., Herter, S., \& Shields, H. (2000). Interest-based natural learning opportunities. Young Exceptional Children Monograph Series No. 2: Natural Environments and Inclusion, 37-48.

Dunst, C. J., Raab, M., Trivette, C., \& Swanson, J. (2010). Community-based everyday child learning opportunities. In R. A. McWilliam (Ed.), Working with families of children with special needs (pp. 60-81). New York: Guilford Press.

Ferguson, C.J. (2009). An Effect Size Primer: A Guide for Clinicians and Researchers. Professional Psychology: Research and Practice, vol. 40, No. 5, 532-538.

Field, A. (2018). Discovering Statistics Using IBM SPSS Statistics (5th Ed). London: Sage.

Greenwood, C. R., Carta, J. J., \& Dawson, H. (2000). Ecobehavioral assessment systems software (EBASS): A system for observation in education settings. In T. Thompson, D. Felce \& F. J. Symons (Eds.), Behavioral observation: Technology and applications in developmental disabilities (pp. 229-251). Baltimore: Paul. H. Brookes.

Grisham-Brown, J., Hemmeter, M.L., \& Pretti-Frontczak, K. (2017). Blended practices for teaching young children in inclusive settings. Baltimore, MD: Brookes Publishing Company.

Hornowska, E., Brzezińska, A. I., Appelt, K., \& Kaliszewska-Czeremska, K. (2014). Rola środowiska w rozwoju małego dziecka - metody badania. Warszawa: Wydawnictwo Naukowe Scholar.

King, B.M., Minium, E.W. (2020). Statystyka dla psychologów i pedagogów. Warszawa: PWN.

Kishida Y, Kemp C. (2006). Measuring Child Engagement in Inclusive Early Childhood Settings: Implications for Practice. Australasian Journal of Early Childhood, 31(2), 14-19.

McBride, B. J., \& Schwartz, I. S. (2003). Effects of teaching early interventionists to use discrete trials during ongoing classroom activities. Topics in Early Childhood Special Education, 23, 5-17.

McGee, G. G., Morrier, M. J., \& Daly, T. (1999). An Incidental Teaching Approach to early intervention for toddlers with autism. Research and Practice for Persons with Severe Disabilities, 24, 133-146.

McWilliam, R.A., (2000). Scale for Teacher's Assessment of Routines Engagement (STARE). Chapel Hill, NC: Frank Porter Graham Child Developmental Center, University of North Carolina at Chapel Hill.

McWilliam, R. A., \& Bailey, D. B. (1992). Promoting engagement and mastery. In D. B. Bailey \& M. Wolery (Eds.), Teaching infants and preschoolers with disabilities (2nd ed., pp. 230-255). New York: Merrill.

McWilliam, R.A. \& Casey, A. M. (2008). Engagement of every child in the preschool classroom. Baltimore, MD: Paul H. Brookes.

McWilliam, R. A., \& de Kruif, R. E. L. (1998). E-Qual III: Children's Engagement Codes. Chapel Hill, NC: Frank Porter Graham Child Development Center, University of North Carolina at Chapel Hill.

McWilliam, R.A., Trivette, C.M. \& Dunst, C.J. (1985). Behavior engagement as a measure of the efficacy of early intervention. Analysis and Intervention in Developmental Disabilities, 5, 33-45.

Murillo, C.P., Garcia Grau, P., Grau, D. (2020). Children's engagement among early childhood education classroom routines. Investigación en el ámbito escolar: Un acercamiento multidimensional a las variables psicológicas y educativas. Volumen IV.

Raspa, M.J., McWilliam R.A., \& Maher Ridley S. (2001). Child Care Quality and Children's Engagement, Early Education and Development, 12, 2, 209-224.

Ridley, S.M., MCwilliam, R.A., \& Oates, C.S. (2000). Observed engagement as an indicator of child care program quality. Early Education and Developmental, 11, 133-146.

Szuman S. (1985). Dzieła wybrane. Studia nad rozwojem psychicznym dziecka. Tom I. Warszawa: Wydawnictwo Szkolne i Pedagogiczne.

Weisberg, D. S., Hirsh-Pasek, K., Golinkoff, R. M., Kittredge, A. K., \&Klahr, D. (2016). Guided play: Principles and practices. Current Directions in Psychological Science, 25, 177-182.

Widerstrom, A. H. (2005). Achieving learning goals through play: Teaching young children with special needs (2nd ed.). Baltimore, MD: Paul H Brookes Pub. Co. 